\title{
Pengembangan Bahan Ajar dengan Pendekatan Student Centered Learning (SCL) pada Materi Kultur Jaringan
}

\author{
Jalilah Azizah Lubis dan Nurmaini Ginting \\ Program Studi Pendidikan Biologi FKIP Universitas Muhammadiyah Tapanuli Selatan \\ E-mail: jalilah_azizah@ymail.com
}

\begin{abstract}
This study aims to determine the teaching materials developed worthy of use as a teaching material for tissue culture in SMA Negeri 5 Padangsidimpuan based on BNSP assessment criteria. Knowing the effectiveness of biological teaching materials with Student Centered Learning approaches on tissue culture materials as reading material for students of grade XI IPA SMA / MA effective and improve students' biology learning outcomes. This research is research of development of 4D model (four D model) suggested by Thiagrajan et al (1974) with research procedure covering Define, Designe, Develope and Dessiminate. The data obtained in the form of quantitative data validator and qualitative data. The product of this research is tissue culture teaching material for high school / MA students. Based on the results of the study, the average percentage of six validators on the teaching materials of students is $80.69 \%$ with the conclusions of the teaching materials worthy of use as teaching materials and this product can be followed by a small revision adding some supporters to optimize the results of the teaching materials by considering the advice and criticism from the validator. Result of questionnaire analysis of student response in general obtained average percentage of $81,24 \%$ mean student have been able to comprehend teaching materials that have been developed and effective for use in learning process.
\end{abstract}

Keywords : Development, Feasibility, Effectiveness, Learning materials

\section{PENDAHULUAN}

Kurikulum 2013 dapat dimaknakan sebagai proses pembelajaran diupayakan melalui pendekatan saintifik untuk meningkatkan kualitas sumber daya manusia khususnya kreativitas dan pengetahuan siswa. Komponen - komponen pembelajaran dirancang terarah dari segi pendekatan dengan multi strategi yang berbasis Student Centered Learning akan memfasilitasi pengembangan pengetahuan, sikap dan keterampilan siswa. Seiring dengan perkembangan ilmu pengetahuan dan tekhnologi, dunia pendidikan juga berkembang semakin pesat. Siswa dituntut untuk lebih aktif dan mampu belajar mandiri. Ketersediaan sarana dan prasarana juga mempengaruhi hasil belajar siswa, sebagian sarana dan prasarana yang sudah ada belum digunakan secara optimal. Kondisi seperti ini tentu saja menjadikan iklim pembelajaran kurang menarik, siswa cenderung menjadi penerima pasif, kurang responsif, kurang kreatif dan kritis, serta kurang memberikan pemahaman yang baik bagi siswa. Pada dasarnya terdapat berbagai faktor yang mempengaruhi keberhasilan pendidikan, antara lain: guru, peserta didik, sarana dan prasarana, lingkungan pendidikan, kurikulum. Dari beberapa faktor tersebut, guru dalam kegiatan proses pembelajaran di sekolah menempati kedudukan yang sangat penting dan tanpa mengabaikan faktor penunjang yang lain, guru sebagai subjek pendidikan sangat menentukan keberhasilan pendidikan itu sendiri. Ilmu biologi sangat berhubungan dengan realita, sampai pada kehidupan sehari - hari. Rendahnya kualitas pendidikan maupun perolehan hasil belajar mata pelajaran biologi para siswa menunjukkan adanya indikasi terhadap rendahnya kinerja belajar siswa dan kemampuan guru dalam mengelola pembelajaran yang berkualitas.

Neil (Nainggolan, 2009), mengkritisi bahwa tidak ada anak yang bermasalah, yang ada adalah para guru dan sekolah yang bermasalah atau tidak kreatif.. Lebih lanjut menurut Slameto (2003), guru yang kurang berinteraksi dengan siswa secara akrab, menyebabkan proses belajar mengajar itu kurang lancar, siswa merasa jauh dari guru sehingga segan berpartisipasi secara aktif dalam belajar.

Salah satu SMA di Kota Padangsidimpuan yang digunakan sebagai observasi awal adalah SMA Negeri I Padangsidimpuan Kelas XI 
terdiri dari 5 ruangan sekolah ini terletak di kecamatan Padangsidimpuan Utara. Pembelajaran biologi khususya materi kultur jaringan diajarkan di kelas XI ditemukan masalah pada hasil belajar siswa masih kurang karena pemahaman tentang kultur jaringan yang hanya menggunakan buku sumber sebagai media dan belum dapat memaknainya. Di SMA Negeri 5 Padangsidimpuan belum sepenuhnya mengoptimalkan pembelajaran berbasis Student Centered Learning yang dapat meningkatkan hasil belajar siswa dan minat siswa dalam belajar. Permasalahan lainnya yang ditemukan adalah rendahnya kemampuan berpikir siswa yang terlihat dari kualitas pertanyaan dan jawaban pada saat proses pembelajaran berlangsung. Siswa kurang mampu menggunakan daya nalar dalam menanggapi informasi yang diterimanya. Disamping juga mengembangkan potensi siswa secara aktif dengan membuat kelompok yang terdiri dari dua orang atau lebih, sehingga dapat menciptakan pola interaksi yang optimal, menggembangkan semangat kebersamaan pada siswa.

Dengan adanya permasalahan, perlu dilakukan penelitian dengn mengembangkan suatu bahan ajar berbasis Student Centered Learning untuk pembelajaran materi kultur jaringan untuk meningkatkan hasil belajar siswa di SMA Negeri 5 Padangsidimpuan.

\section{METODE PENELITIAN}

Penelitian yang digunakan adalah penelitian pengembangan (Research and development/R\&D). Penelitian pengembangan ini akan menghasilkan produk berupa bahan ajar tertentu yang akan diuji kelayakan dan keefektifan bahan ajar dalam proses pembelajaran. Prosedur langkah penelitian pengembangan dengan model pengembangan 4D (four D) terdiri atas 4 tahap utama yaitu: (1) Define (Pembatasan), (2) Design (Perancangan), (3) Develop (Pengembangan) dan Disseminate (Penyebaran), atau di adaptasi Model 4-P, yaitu Pendefinisian, Perancangan, Pengembangan, dan Penyebaran. Tahap prosedur pelaksanaan penelitian : Tahap observasi awal, Pada tahap ini dilakukan dan didefinisikan syarat-syarat pembelajaran di awali dengan analisis tujuan dari batasan materi yang dikembangkan perangkatnya.

Persiapan penelitian meliputi: (a) Pengembangan bahan ajar, (b) Pembuatan perangkat pembelajaran, (c) Penyusunan instrumen penelitian, instrumen dalam penelitian ini meliputi: Lembar penilaian bahan ajar oleh pakar,Lembar penilaian ini diperuntukkan bagi pakar yang akan menilai bahan ajar kultur jaringan berbasis kinerja siswa. Pakar yang dimaksud adalah dosen atau orang yang ahli pada bidang yang berhubungan dengan penelitian.Pedoman wawancara tanggapan guru sebagai pedoman melakukan wawancara dengan guru untuk mengetahui tanggapan guru tentang bahan ajar materi kultur jaringan dengan pendekatan SCL yang digunakan dalam proses pembelajaran. Angket tanggapan siswa digunakan untuk mengetahui tanggapan siswa tentang bahan ajar materi kultur jaringan dengan pendekatan SCL yang digunakan dalam proses pembelajaran. Lembar observasi kinerja siswa.

Penelitian dilaksanakan oleh pakar, melaksanakan revisi I,uji coba I, menerapkan bahan ajar dalam skala kecil pada pembelajaran materi kultur jaringan dengan pendekatan SCL di kelas $\mathrm{XI}_{2}$ SMAN 5 Padangsidimpuan. Revisi II, kemudian uji coba II menerapkan bahan ajar dalam skala besar pada pembelajaran kultur jaringan pada kelas $\mathrm{XI}_{1}$ dan $\mathrm{XI}_{3}$ SMAN 5 Padangsidimpuan. Selanjutnya revisi III sehingga diperoleh hasil akhir. Analisis data dilakukan secara deskriptif kuantitatif, mulai dari penilaian pakar tehadap bahan ajar, tanggapan guru tentang pembelajaran, tanggapan siswa tentang bahan ajar dan hasil belajar siswa setelah menggunakan bahan ajar tersebut diolah menggunakan uji -t pada tahap $\alpha 5 \%$.

\section{HASIL DAN PEMBAHASAN}

Pada tahap define didapatkan hasil wawancara dengan tiga guru Biologi di SMA 5 didapatkan bahwa masalah dasar yang terdapat pada pembelajaran kultur jaringan siswa masih belum bisa memahami dan menganalisa sejauh mana jaringan tersebut bisa menjadi tumbuhan yang lengkap dan belum dapat dilihat proses kultur jaringan secara langsung. Siswa kurang semangat belajar kultur jaringan disebabkan buku paket yang digunakan hanya sekilas membahas mengenai kultur jaringan tanaman sehingga pembelajaran yang berlangsung kurang menyenangkan. Selain itu, sumber belajar yang digunakan oleh guru dalam pembelajaran antara lain : Erlangga dan Esis. Berdasarkan angket siswa yang belajar menggunakan buku paket dalam pelaksanaan pembelajaran $85,12 \%$, menggunakan LKS $14,88 \%$ yang berasal dari perpustakaan. Dari hasil ulangan harian didapatkan hanya 26,66 \% 
yang memahami isi buku, 43,33\% cukup memahami isi, dan $30 \%$ yang kurang memahami materi kultur jaringan. Pengembangan bahan ajar didasari dengan kompetensi inti dan kompetensi dasar kurikulum 2013.

Pada tahap perancangan bahan ajar siswa yang dikembangkan berpusat pada siswa dimana di dalam buku terjadi percakapan yang diharapkan dapat dijawab siswa dengan jawaban bahasa sendiri sesuai dengan pemahamannya pada saat membaca bahan ajar tersebut. Di dalam buku juga disajikan pertanyaan-pertanyaan selingan yang berhubungan dengan materi kultur jaringan. Media yang digunakan disini adalah bahan ajar dengan pendekatan Student Centered Learning (SCL) pada materi kultur jaringan. Bahan ajar ini diperuntukkan untuk siswa kelas XI SMA. Bahan ajar ini dikembangkan berisi materi kultur jaringan tanaman mulai dari tahapan pemahaman apa itu kultur jaringan sampai pada tahapan pelaksanaan kultur jaringan tanaman. Bahan ajar inijuga dilengkapi dengan prakata, daftar isi, kompetensi inti, kompetensi dasar, indikator dan tujuan pembelajaran, peta konsep, pustaka dan glosarium. Pada tahap pengembangan kegiatan pertama adalah validasi bahan ajar dilakukan dengan memberikan draft bahan ajar biologi berbasis student centered learning (SCL) disertai dengan instrumen validasi ahli. Hasil validator ahli terhadap kualitas bahan ajar ditunjukkan pada Tabel 1.

Tabel 1. Hasil penilaian validator

\begin{tabular}{clc}
\hline No & Nama & Nilai (\%) \\
\hline 1 & Validator Ahli 1 & 77,7 \\
2 & Validator Ahli 2 & 77,7 \\
3 & Validator Materi 1 & 77,5 \\
4 & Validator Materi 2 & 80,0 \\
5 & Validator Pengguna 1 & 87,5 \\
6 & Validator Pengguna 2 & 83,7 \\
\hline \multicolumn{2}{l}{ Rata-rata } & \\
\hline \multicolumn{2}{l}{ Kualifikasi : Valid } \\
Deskripsi : Produk dapat dilanjutkan dengan revisi kecil dan dimanfaatkan di lapangan
\end{tabular}

Diperoleh rata-rata $80,69 \%$, dengan revisi kecil dan bisa dimanfaatkan dalam pembelajaran. Adapun data kualitatif berupa saran dan kritikan untuk lebih fokus pada pembelajaran yang berpusat pada siswa dimana guru hanya berperan sebagai fasilitator saja. Data respon siswa terhadap bahan ajar didapatkan rata - rata 81,24 , yang menyatakan bahwa siswa senang dan paham akan isi bahan ajar tersebut. Tahapan selanjutnya dilakukan penyebaran instrumen soal sebanyak 15 soal essay untuk mengetahui kemampuan pengetahuan dan keterampilan siswa setelah pembelajaran berlangsung.

Selanjutnya uji coba yang dilakukan pada siswa sebanyak 12 siswa dalam skala kecil pada tanggal 6 Juni 2017 di kelas XI IPA 1, dimana siswa disini sudah pernah belajar kultur jaringan pada semester ganjil. Data respon siswa terhadap bahan ajar diberikan kepada siswa, data respon siswa terhadap bahan ajar dapat dilihat pada Tabel 2 .

Tabel 2. Data respon siswa terhadap bahan ajar

\begin{tabular}{|c|c|c|c|c|c|c|c|c|}
\hline \multirow{2}{*}{ No } & \multirow{2}{*}{ Indikator/Aspek yang Diamati } & \multicolumn{4}{|c|}{ Skala } & \multirow[t]{2}{*}{$\mathbf{N}$} & \multirow{2}{*}{$\begin{array}{c}\text { Persentase } \\
(\%)\end{array}$} & \multirow[t]{2}{*}{ Ket } \\
\hline & & 1 & 2 & 3 & 4 & & & \\
\hline \multirow[t]{6}{*}{1.} & Perasaan siswa senang terhadap komponen : & & & & & & & \\
\hline & a. Materi Pelajaran & & & 4 & 8 & 12 & 75,00 & \\
\hline & b. Buku Siswa & 1 & 2 & 1 & 8 & 12 & 83,33 & \\
\hline & c. Suasana belajar di kelas & 1 & & 1 & 8 & 12 & 66,67 & \\
\hline & d. Pendekatan Student Centered Learning (SCL) & & 1 & 2 & 8 & 12 & 83,33 & \\
\hline & Rata - rata & & & & & & 77,08 & Baik \\
\hline \multirow[t]{7}{*}{2.} & Pendapat siswa terhadap komponen : & & & & & & & \\
\hline & a. Materi Pelajaran & & & & 1 & 12 & 100 & \\
\hline & b. Kegiatan siswa & & & 4 & 2 & 12 & 75,00 & \\
\hline & c. Suasana belajar di kelas & 2 & & 1 & 8 & 12 & 66,67 & \\
\hline & d. Cara guru mengajar & & 1 & 0 & & 12 & 83,33 & \\
\hline & & & & 2 & 8 & & & \\
\hline & Rata-rata & & & & & & 81,25 & Sangat Baik \\
\hline
\end{tabular}




\begin{tabular}{|c|c|c|c|c|c|c|c|c|}
\hline \multirow{2}{*}{ No } & \multirow{2}{*}{ Indikator/Aspek yang Diamati } & \multicolumn{4}{|c|}{ Skala } & \multirow[t]{2}{*}{$\mathbf{N}$} & \multirow{2}{*}{$\begin{array}{c}\text { Persentase } \\
(\%)\end{array}$} & \multirow[t]{2}{*}{ Ket } \\
\hline & & 1 & 2 & 3 & 4 & & & \\
\hline 3. & $\begin{array}{l}\text { Apakah kamu berminat mengikuti belajar } \\
\text { selanjutnya }\end{array}$ & & & & & 12 & 83,33 & Sangat Baik \\
\hline \multirow[t]{6}{*}{4.} & $\begin{array}{l}\text { Bagaimana pendapatmu tentang bahan ajar: } \\
\text { a. Apakah kamu dapat memahami bahasa yang } \\
\text { digunakan dalam bahan ajar? }\end{array}$ & & 1 & 2 & 8 & 12 & 83,33 & \\
\hline & b. Apakah kamu tertarik pada penampilan & & & & & & & \\
\hline & $\begin{array}{l}\text { Tulisan, } \\
\text { Gambar }\end{array}$ & 1 & $\begin{array}{l}1 \\
2\end{array}$ & $\begin{array}{l}2 \\
1\end{array}$ & $\begin{array}{l}9 \\
8\end{array}$ & $\begin{array}{l}12 \\
12\end{array}$ & $\begin{array}{l}91,60 \\
83,33\end{array}$ & \\
\hline & Letak gambar yang terdapat pada bahan ajar & & & 4 & 8 & 12 & 75,00 & \\
\hline & Rata-rata & & & & & & 83,31 & Sangat Baik \\
\hline & Total rata-rata & & & & & & 81,24 & Sangat Baik \\
\hline
\end{tabular}

Berdasarkan Hasil analisis data angket respon siswa yang ditunjukkan pada tabel 2 . diatas diperoleh data sebagai berikut. Aspek pertama yaitu perasaan siswa terhadap bahan ajar sebesar 77,08 \% siswa nyatakan senang, Pendapat siswa terhadap komponen baru $81,25 \%$ siswa menyatakan mudah dan keinginan siswa untuk mengikuti pelajaran selanjutnya $83,33 \%$ dan pendapat siswa tentang bahan ajar $83,31 \%$ menyatakan senang, jadi total rata - rata yang didapatkan $81,24 \%$ menyatakan bahwa bahan ajar layak digunakan untuk mengenalkan dan memperluas wawasan ssiswa tentang kultur jaringan.

Kegiatan kedua yatu uji coba terbatas yang dilakukan pada hari yang sama dimana diikuti oleh siswa kelas XI SMA sebanyak 12 orang dari SMA Negeri 5 Padangsidimpuan. Data uji keterbacaan dan tingkat kesulitan terhadap bahan ajar diperoleh dengan memberikan angket kepada siswa. Data uji keterbacaan dan tingkat kesulitan dapat dilihat pada Tabel 3.

Tabel 3. Data Uji Keterbacaan dan Tingkat Kesulitan Bahan Ajar

\begin{tabular}{|c|c|c|}
\hline No & Indikator/Aspek yang Diamati & Persentase (\%) \\
\hline \multirow[t]{6}{*}{1.} & Keterbacaan buku siswa : & \\
\hline & a. Materi Pelajaran yang disajikan & 75,00 \\
\hline & b. Bahasa yang digunakan & 83,33 \\
\hline & c. Kalimat yang disajikan & 75,00 \\
\hline & d. Gambar yang ditampilkan & 83,33 \\
\hline & e. Kelengkapan penyajian & 75,00 \\
\hline \multicolumn{2}{|r|}{ Rata - rata } & 78,33 \\
\hline \multirow[t]{4}{*}{2.} & Komponen kegiatan siswa : & \\
\hline & a. Latihan yang diberikan & 100 \\
\hline & b. Petunjuk penggunaan & 75,00 \\
\hline & c. Kalimat yang disajikan & 75,00 \\
\hline \multicolumn{2}{|r|}{ Rata-rata } & $\mathbf{8 3 , 3 3}$ \\
\hline 3. & $\begin{array}{l}\text { Keterbacaan kegiatan siswa } \\
\text { a. Bahasa yang digunakan } \\
\text { b. Latihan soal yang disajikan }\end{array}$ & $\begin{array}{l}83,33 \\
66,66\end{array}$ \\
\hline \multicolumn{2}{|c|}{ Rata-rata } & 74,99 \\
\hline 4. & Soal Uji Kompetensi pada siswa & 66,66 \\
\hline \multicolumn{2}{|r|}{ Total rata-rata } & 75,82 \\
\hline
\end{tabular}

Aspek pertama yang dilihat keterbacaan bahan ajar dimana diperoleh rata rat 78,33\%, yang menyatakan bahwa buku siswa mudah dibaca, bahasa yang digunakan mudah dipahami, kalimat penyajiannya mudah untuk dipahamidengan gambar yang jelas, dan penyajian yang lengkap. Aspek kedua yang dilihat komponen kegiatan siswa diperoleh rata - rata sebesar $83,33 \%$ jumlah ini menyimpulkan bahwa latihan, petunjuk dan kalimat arahan untuk penyajian sudah layak dan mudah untuk dipahami. Aspek ketiga keterbacaan kegiatan siswa didapatkan rata rata $74,99 \%$ berarti siswa pahamakan kegiatan yang akan dijalankan akan tetapi perlu arahan yang lebih jelas dengan melakukan revisi sederhana. Sedangkan aspek keempat adalah uji kompetensi siswa dimana didapatkan rata -rata $66,66 \%$. Dari data ini didapatkan bahwa siswa masih agak sulit dalam mengerjakan sola kompetensi karena soal yang dibuat rata rata berpikir kritis. 


\section{KESIMPULAN}

Besar persentase rata - rata dari enam validator terhadap bahan ajar siswa yaitu 80,69 $\%$ dimana produk dapat dilanjutkan dengan revisi kecil menambahkan beberapa pendukung untuk mengoptimalkan hasil bahan ajar tersebut dengan mempertimbangkan saran dan kritikan dari validator. Hasil analisis angket respon siswa secara umum diperoleh rata - rata persentase $81,24 \%$ artinya siswa sudah dapat memahami bahan ajar yang telah dikembangkan dan efektif untuk digunakan pada proses pembelajaran. Hasil belajar siswa juga rata - rata diatas KKM yaitu 84,75 dimana hanya 3 siswa yang tidak tuntas dan 4 siswa pada batas tuntas dan 21 siswa nilainya lebih dari KKM mata pelajaran.

\section{UCAPAN TERIMAKASIH}

Penulis ucapkan terimakasih kepada Direktorat Riset dan Pengabdian Masyarakat Direktorat Jenderal Penguatan Riset dan Pengembangan Kementerian Riset, Teknologi, dan Pendidikan Tinggi yang telah membiayai penelitian ini, Lembaga Penelitian dan Pengabdian Masyarakat UMTS yang telah memfasilitatori pelaksanaan penelitian. Semua yang memfasilitasi pelaksanaan di SMA Negeri 5 Padangsidimpuan dan semua validator dan semua pihak yang tidak bisa penulis sebutkan dalam naskah ini.

\section{DAFTAR PUSTAKA}

Arends, R. I. 2008. Learning to Teach: Belajar untuk Mengajar. Buku Dua. (Penterjemah: Helly
Prayitno Soetjipto dan Sri Mulyantini Soetjipto). Pustaka Pelajar. Yogyakarta.

Armstrong N., Chang S., Brickman M. 2007. Cooperative Learning in Industrial-Sized Biology Classes, CBE-Life Sciences Education, (6)163-171.

Attard, Angela, et all. 2010. Student Centred Learning, Toolkit for students Staffs, and Higher Education Institution. Education International and the European Student Union, Brussel, Belgia.(Penerjemah Prof. Dr. Dede Rosyada, MA)

Daryanto. 2009. Panduan Proses Pembelajaran Kreatif dan Inovatif. AV Publisher. Jakarta.

Harahap, F .2011. Kultur Jaringan. Medan. Unimed Pers.

Hartono, 2008. Statistik Untuk Penelitian, Yogyakarta: Pustaka Pelajar.

Orclich, D.C., et al. 1998. Teaching Strategies. Boston New York: Houghton Mifflin Company.

Nasution, Syaukani. 2008. Berbagai Pendekatan dalam Proses Belajar \& Mengajar, Jakarta. Bumi Aksara.

Prastowo Andi. 2011, Panduan Kreatif Membuat Bahan Ajar Inovatif Menciptakan Metode Pembelajaran yang Menarik Dan Menyenangkan. Yogyakarta. Diva press.

Slameto. 2003. Belajar dan Faktor-Faktor yang Mempengaruhinya. Jakarta.Rineka Cipta.

Suprawoto, N.A. 2009. Mengembangkan Bahan Ajar Dengan Menyusun Modul. On line at www.scribd.com [Accessed 26 April 2016].

Sudijono, A. 2006. Pengantar Statistik Pendidikan. Jakarta. PT. Raja Grafindo Persada.

Sudrajat, A. 2009. Konsep Pengembangan Bahan Ajar. On Line at http://dikdasmen.org [Accessed 15 Mei 2010]. 